\title{
Use of Single-Injection Recombinant Vesicular Stomatitis Virus Vaccine to Protect Nonhuman Primates Against Lethal Nipah Virus Disease
}

\author{
Chad E. Mire, Joan B. Geisbert, Krystle N. Agans, Krista M. Versteeg, Daniel J. Deer, \\ Benjamin A. Satterfield, ${ }^{1}$ Karla A. Fenton, Thomas W. Geisbert
}

\begin{abstract}
Nipah virus (NiV) is a zoonotic pathogen that causes high case-fatality rates (CFRs) in humans. Two NiV strains have caused outbreaks: the Malaysia strain $\left(\mathrm{NiV}_{\mathrm{M}}\right)$, discovered in 1998-1999 in Malaysia and Singapore ( $\approx 40 \%$ CFR); and the Bangladesh strain $\left(\mathrm{NiV}_{\mathrm{B}}\right)$, discovered in Bangladesh and India in 2001 ( $\approx 80 \%$ CFR). Recently, $\mathrm{NiV}_{\mathrm{B}}$ in African green monkeys resulted in a more severe and lethal disease than $\mathrm{NiV}_{\mathrm{M}}$. No NiV vaccines or treatments are licensed for human use. We assessed replication-restricted singleinjection recombinant vesicular stomatitis vaccine NiV vaccine vectors expressing the NiV glycoproteins against $\mathrm{NiV}_{\mathrm{B}}$ challenge in African green monkeys. All vaccinated animals survived to the study endpoint without signs of NiV disease; all showed development of NiV F Ig, NiV G IgG, or both, as well as neutralizing antibody titers. These data show protective efficacy against a stringent and relevant $\mathrm{NiV}_{\mathrm{B}}$ model of human infection.
\end{abstract}

$\mathrm{N}$ ipah virus $(\mathrm{NiV})$ and Hendra virus $(\mathrm{HeV})$ are highly pathogenic zoonotic agents in the paramyxovirus genus Henipavirus. Human case-fatality rates (CFRs) for these viruses historically have ranged from $40 \%$ to $>90 \%$ (1). $\mathrm{NiV}$ is categorized as a Biosafety Level 4 (BSL-4) pathogen because of the substantial illness and death it causes and the lack of approved vaccines and therapeutic drugs for human use. In 2015, the World Health Organization listed $\mathrm{NiV}$ as a priority pathogen because it is likely to cause severe outbreaks and, in early 2018, placed NiV on the Blueprint list of priority diseases (https://www.who. int/blueprint/priority-diseases). This WHO designation was bolstered because of a deadly NiV outbreak (CFR 89\%) during spring 2018 in southwestern India, where NiV had not previously been reported (2).

Author affiliations: Galveston National Laboratory, Galveston, Texas, USA; University of Texas Medical Branch, Galveston

DOI: https://doi.org/10.3201/eid2506.181620
Bats of the genus Pteropus are the primary reservoir in nature for NiV (3), but several other mammal species can be infected by NiV (4-7). Analysis of NiV genomes has identified $2 \mathrm{NiV}$ strains responsible for outbreaks: Malaysia strain $\mathrm{NiV}_{\mathrm{M}}$ and Bangladesh strain $\left(\mathrm{NiV}_{\mathrm{B}}\right) . \mathrm{NiV}_{\mathrm{M}}$ caused the first identified outbreak of NiV during 1998-1999 in Malaysia and Singapore $(\approx 270$ persons infected; CFR $\approx 40 \%$ ) $(8,9)$ and perhaps was responsible for a 2014 outbreak in the Philippines (CFR $\approx 52 \%$ ); however, this speculation is based on short genomic reads, so the NiV strain that caused this outbreak is not known (10). $\mathrm{NiV}_{\mathrm{B}}$ has caused repeated outbreaks in Bangladesh and northeastern India; outbreaks occurred almost every year during 2001-2015 (11-15). These $\mathrm{NiV}_{\mathrm{B}}$ outbreaks had higher CFRs, averaging $\approx 80 \%$ (14), and showed documented human-to-human transmission $(11,16)$.

Eight experimental preventive candidate vaccines against henipaviruses have been evaluated in $\mathrm{NiV}_{\mathrm{M}}$ animal models: 1) canarypox and 2) vaccinia viruses encoding the $\mathrm{NiV}_{\mathrm{M}}$ fusion protein $(\mathrm{F})$ or the $\mathrm{NiV}_{\mathrm{M}}$ attachment protein $(\mathrm{G})$ that have shown protection against $\mathrm{NiV}_{\mathrm{M}}$ in hamsters and pigs $(17,18)$; 3) a recombinant adeno-associated vaccine expressing the $\mathrm{NiV}_{\mathrm{M}} \mathrm{G}$ protein that completely protected hamsters against homologous $\mathrm{NiV}_{\mathrm{M}}$ challenge (19); 4) recombinant vesicular stomatitis viruses (rVSVs) expressing the $\mathrm{NiV}_{\mathrm{M}} \mathrm{F}$ protein or the $\mathrm{NiV}_{\mathrm{M}} \mathrm{G}$ protein that had $100 \%$ efficacy in hamsters against $\mathrm{NiV}_{\mathrm{M}}(20)$; 5) rVSVs expressing the $\mathrm{NiV}_{\mathrm{B}} \mathrm{F}$ protein or the $\mathrm{NiV}_{\mathrm{B}} \mathrm{G}$ protein that completely protected ferrets from $\mathrm{NiV}_{\mathrm{M}}$ disease $(21)$; 6) an rVSV expressing the Zaire ebolavirus (EBOV) glycoprotein (GP) and the $\mathrm{NiV}_{\mathrm{M}} \mathrm{G}$ protein (rVSV-EBOV-GP-NiVG) that demonstrated efficacy in $\mathrm{NiV}_{\mathrm{M}}$ hamster (22) and African green monkey (Chlorocebus aethiops) (23) models; 7) a recombinant measles virus vector expressing the $\mathrm{NiV}_{\mathrm{M}} \mathrm{G}$

${ }^{1}$ Current affiliation: Mayo Clinic, Rochester, Minnesota, USA. 
protein that had efficacy in the $\mathrm{NiV}_{\mathrm{M}}$ African green monkey model (24); and 8) a recombinant subunit vaccine based on the $\mathrm{HeV} \mathrm{G}$ protein $\left(\mathrm{sG}_{\mathrm{HeV}}\right)$ that completely protected small animals against lethal $\mathrm{HeV}$ and $\mathrm{NiV}_{\mathrm{M}}$ infections (25-27) and was efficacious in the robust African green monkey model of $\mathrm{HeV}(28)$ and $\mathrm{NiV}_{\mathrm{M}}$ infection (29). Of 8 vaccines, the $\mathrm{sG}_{\mathrm{HeV}}$ vaccine is furthest along in evaluation; it has received licensure as a veterinary vaccine for $\mathrm{HeV}$ in horses (Equivac $\mathrm{HeV}$, Zoetis, https://www.zoetis. com) in Australia and is being considered as a human vaccine against $\mathrm{NiV}$. When tested against $\mathrm{NiV}$, these 8 vaccine vectors have been tested only against $\mathrm{NiV}_{\mathrm{M}}$ infection in animal models, and although the antigenicity of these vaccines should not be a concern given that $\mathrm{HeV} \mathrm{G}$ is an immunogen against $\mathrm{NiV}_{\mathrm{M}}$ infection, there are new data on the $\mathrm{NiV}_{\mathrm{B}}$ African green monkey model to consider as far as dose/regimen of vaccines.

$\mathrm{NiV}_{\mathrm{B}}$ infection in African green monkeys is more pathogenic than $\mathrm{NiV}_{\mathrm{M}}$ infection (30). This difference resulted in significantly reduced efficacy of antibody therapy because of temporal differences in viral load. Specifically, the human monoclonal antibody m102.4 that had been shown to completely protect African green monkeys against lethal $\mathrm{NiV}_{\mathrm{M}}$ disease when treatment was delayed until day 5 after virus exposure provided no protection when African green monkeys were challenged with $\mathrm{NiV}_{\mathrm{B}}$ and treated beginning at day 5 after virus challenge $(30,31)$. Considering these new data, the current vaccines against $\mathrm{NiV}$ need to be evaluated for possible differences in dose/regimen against the more pathogenic $\mathrm{NiV}_{\mathrm{B}}$ infection in the robust African green monkey model. To assess single-dose vaccine efficacy, we evaluated the rVSV vaccine vectors expressing either the $\mathrm{NiV}_{\mathrm{B}} \mathrm{F}$ or $\mathrm{NiV}_{\mathrm{B}} \mathrm{G}$ proteins 28 days after a single-dose vaccination in the $\mathrm{NiV}_{\mathrm{B}}$ African green monkey model, which most faithfully recapitulates human disease $(5,30)$.

\section{Methods}

\section{rVSV Vaccine Vectors and $\mathrm{NiV}_{\mathrm{B}}$ Challenge Stock}

We recovered the $r V S V \mathrm{NiV}_{\mathrm{B}}$ vaccines $\left(\mathrm{rVSV}-\Delta \mathrm{G}-\mathrm{NiV}_{\mathrm{B}} /\right.$ F-GFP and rVSV- $\Delta$ G-NiV ${ }_{B} /$ G-GFP) and rVSV- $\Delta$ G-GFP using methods as previously described $(21,32)$. The isolate of $\mathrm{NiV}_{\mathrm{B}}$ used in this vaccine study was obtained from a fatal human case (200401066) described previously (30).

\section{Statistical Analyses}

Animal studies in BSL-4 and nonhuman primate work generally restrict the number of animals used, the volume of biological samples that can be obtained, and the ability to repeat assays independently and thus limit statistical analysis. Consequently, we present these data as the mean calculated from replicate samples, not replicate assays, and error bars represent SD across replicates (Figure 1, panels B, C, and D).

\section{Animal Ethics Considerations and Experiments}

Healthy adult African green monkeys were handled in the animal BSL-4 containment space at the Galveston National Laboratory (Galveston, TX, USA). Research was approved under animal protocol 1310040 by the University of Texas Medical Branch Institutional Animal Care and Use Committee (Appendix, https://wwwnc.cdc.gov/EID/ article/25/6/18-1620-App1.pdf).

We used 10 adult African green monkeys weighing 3.5$6.0 \mathrm{~kg}$ in this study. One animal served as control (received $\mathrm{G}_{\mathrm{In}}$ * rVSV- $\Delta \mathrm{G}-\mathrm{GFP}$ ), and 3 animals per vaccine group received $\mathrm{G}^{*} \quad$ rVSV- $\Delta \mathrm{G}-\mathrm{NiV}_{\mathrm{B}} / \mathrm{F}-\mathrm{GFP}, \mathrm{G}^{*} \quad \mathrm{rVSV}^{-} \Delta \mathrm{G}-\mathrm{NiV}_{\mathrm{B}} /$ $\mathrm{G}-\mathrm{GFP}$, or $\mathrm{rVSV} \Delta \mathrm{G}-\mathrm{NiV}_{\mathrm{B}} / \mathrm{F} / \mathrm{G}$. For vaccination, animals were anesthetized with ketamine and vaccinated with $\approx 10^{7}$ PFU by intramuscular injection (day -28 ). Twenty-eight days after vaccination, the animals were exposed to $\approx 5 \times 10^{5}$ PFU of $\mathrm{NiV}_{\mathrm{B}}$; the dose was equally divided between the intratracheal and the intranasal routes for each animal. Animals were monitored for clinical signs of illness (i.e., temperature, respiration quality, blood count, and clinical pathologic findings) at $0,3,6,8,10,15,21$, and 28 days postchallenge (dpc).

\section{$\mathrm{NiV}_{\mathrm{B}}$ Serum Neutralization Assays}

We determined neutralization titers against $\mathrm{NiV}_{\mathrm{B}}$ using a conventional serum neutralization assay. In brief, we serially diluted serum 5-fold or 2-fold depending on magnitude of neutralization titers and incubated with $\approx 100 \mathrm{PFU}$ of $\mathrm{NiV}_{\mathrm{B}}$ for $1 \mathrm{~h}$ at $37^{\circ} \mathrm{C}$, as previously described (30).

\section{RNA Isolation from $\mathrm{NiV}_{\mathrm{B}}$-Infected African Green Monkeys}

We isolated RNA from $\mathrm{NiV}_{\mathrm{B}}$-infected animals as described previously (30). For viremia, we added $100 \mu \mathrm{L}$ of blood to $600 \mu \mathrm{L}$ of AVL viral lysis buffer (QIAGEN, https://www.qiagen.com) for RNA extraction. For virus load in tissue, we stored $\approx 100 \mathrm{mg}$ in $1 \mathrm{~mL}$ RNAlater (QIAGEN) for $7 \mathrm{~d}$ to stabilize RNA, removed the RNA later completely, and homogenized tissues in $600 \mu \mathrm{L}$ RLT buffer (QIAGEN) in a 2-mL cryovial using a tissue lyser (QIAGEN) and ceramic beads.

\section{Detection of $\mathrm{NiV}_{\mathrm{B}}$ Load}

We isolated RNA from blood or tissues and assessed it using primers and probe targeting the $\mathrm{N}$ gene and the intergenic region between $\mathrm{N}$ and $\mathrm{P}$ genes of $\mathrm{NiV}_{\mathrm{B}}$ for quantitative reverse transcription PCR (qRT-PCR). The probe used was 6FAM-5'CGT CAC ACA TCA GCT CTG ACA A 3'-6TAMRA (Life Technologies, https://www.thermofisher.com), as described previously (30).

\section{Hematology and Serum Biochemistry}

We assessed clinical pathology of $\mathrm{NiV}_{\mathrm{B}}$-infected African green monkeys by hematology and serum biochemistry 
analysis as described previously (30). We performed the hematology assays using a laser-based hematologic analyzer (Beckman Coulter, https://www.beckmancoulter.com) and serum biochemistry analysis using a Piccolo point-ofcare analyzer and Biochemistry Panel Plus analyzer discs (Abaxis, https://www.abaxis.com).

\section{Histopathology and Immunohistochemistry}

We performed necropsies on all animals and collected tissue samples of all major organs. We performed histopathologic and immunohistochemical examination and analyses as described previously (30).

\section{Results}

\section{Immunization of African Green Monkeys and Measur- ing the Humoral Immune Response}

Previously, single-injection, single-round replication rVSV vaccine vectors expressing the $\mathrm{NiV}_{\mathrm{B}} \mathrm{F}$ or $\mathrm{NiV}_{\mathrm{B}} \mathrm{G}$ proteins were described, characterized, and shown to be efficacious against $\mathrm{NiV}_{\mathrm{B}}$ challenge in ferrets (21). To assess the efficacy of these vectors in the $\mathrm{NiV}_{\mathrm{B}}$ African green monkey model, 4 groups of African green monkeys received a single intramuscular vaccination of rVSV vectors on day -28 (Figure 2). To analyze the antibody response to $\mathrm{rVSV}-\Delta \mathrm{G}^{-N i V_{\mathrm{B}}}$ vaccinations, we assessed circulating antibodies for neutralization activity against $\mathrm{NiV}_{\mathrm{B}}$ before and after vaccination by using a $50 \%$ plaque-reduction neutralization titer $\left(\mathrm{PRNT}_{50}\right)$ assay. All 4 groups had no detectable neutralizing antibody titers before vaccination (Table 1, day -28). On the day of challenge, the control animal (C-1) did not have detectable neutralizing antibody titers against $\mathrm{NiV}_{\mathrm{B}}$, whereas all animals from the specific $\mathrm{NiV}$ protein vaccination groups $(\mathrm{F}, \mathrm{G}$, and $\mathrm{F} / \mathrm{G})$ had detectable neutralizing antibodies against $\mathrm{NiV}_{\mathrm{B}}$ (Table 1, day 0). Overall, the detectable neutralizing antibody response against $\mathrm{NiV}_{\mathrm{B}}$ reached a 1:640 dilution titer in the $\mathrm{G}$ and $\mathrm{F} / \mathrm{G}$ groups and from 1:160 to 1:640 in the $\mathrm{F}$ group.

\section{$\mathrm{NiV}_{B}$ Challenge and Viral Load of Vaccinated African Green Monkeys}

To determine the efficacy of the rVSV- $\Delta \mathrm{G}-\mathrm{NiV}_{\mathrm{B}}$ vectors against $\mathrm{NiV}_{\mathrm{B}}$ disease in African green monkeys, we challenged these animals by combined intratracheal and intranasal routes with a lethal challenge dose of $\mathrm{NiV}_{\mathrm{B}}$ on day 0 (Figure 1). All African green monkeys were closely monitored for up to $28 \mathrm{dpc}$ for clinical signs of illness. The $\mathrm{NiV}_{\mathrm{B}}$ antigen vaccinated animals in the $F(F-1-3), G(G-1-3)$, and $F / G$ (F/G-1-3) groups showed no signs of clinical illness (Table 2 ) and were $100 \%$ protected against $\mathrm{NiV}_{\mathrm{B}}$ challenge (Figure 1 , panel A), whereas the animal in the nonspecific vaccinated control group (C-1) exhibited clinical signs of disease (Table 2) and died of infection on day 8 (Figure 1, panel A). In addition, the control animal was the only $\mathrm{NiV}_{\mathrm{B}}$-infected animal to have lymphopenia and serosanguinous nasal discharge during the course of disease (Table 2).

To determine the level of $\mathrm{NiV}_{\mathrm{B}}$ replication in animals after challenge, we assessed viral load by qRT-PCR on
Figure 1. Protection of African green monkeys (Chlorocebus aethiops) from Nipah virus Bangladesh strain $\left(\mathrm{NiV}_{\mathrm{B}}\right)-$ mediated disease and viral load. A) Kaplan-Meier survival curve for each vaccine group and historical controls after $\mathrm{NiV}_{\mathrm{B}}$ challenge: controls (vaccine, $\mathrm{n}=$ 1 ; historical, $n=14), F$ group ( $n$ $=3), \mathrm{G}$ group $(n=3)$, and $F / G$ group $(n=3)$. C-D) Viral load in the animals as detected by $\mathrm{NiV}_{\mathrm{B}}$ GEq by reverse transcription quantitative PCR from nasal swab samples: as GEq per swab (B), oral swab samples as GEq per swab (C), and blood as $\mathrm{GEq} / \mathrm{mL}$ (D). Red, control group $\left(G_{\text {Ind }}{ }^{*} r V S V-\Delta G-G F P\right.$ expressing no glycoprotein); blue, $F$ group $\left(G_{\text {Ind }}{ }^{*}\right.$ rVSV-NiV ${ }_{B} / F-G F P$ expressing the $\mathrm{NiV}_{\mathrm{B}} \mathrm{F}$ protein); yellow, $G$ group $\left(G_{\text {Ind }}{ }^{*} r V S V-\right.$ $\mathrm{NiV}_{B} / \mathrm{G}-\mathrm{GFP}$ expressing the $\mathrm{NiV}_{\mathrm{B}} \mathrm{G}$ protein); green, F/G group (single-cycle infectious virions with $\mathrm{NiV}_{\mathrm{B}} \mathrm{F}$ and $\mathrm{G}$ proteins on the cell surface). Error bars indicate SD. C, control; $\mathrm{F}$, fusion; $\mathrm{G}$, attachment; GEq, genome equivalent.
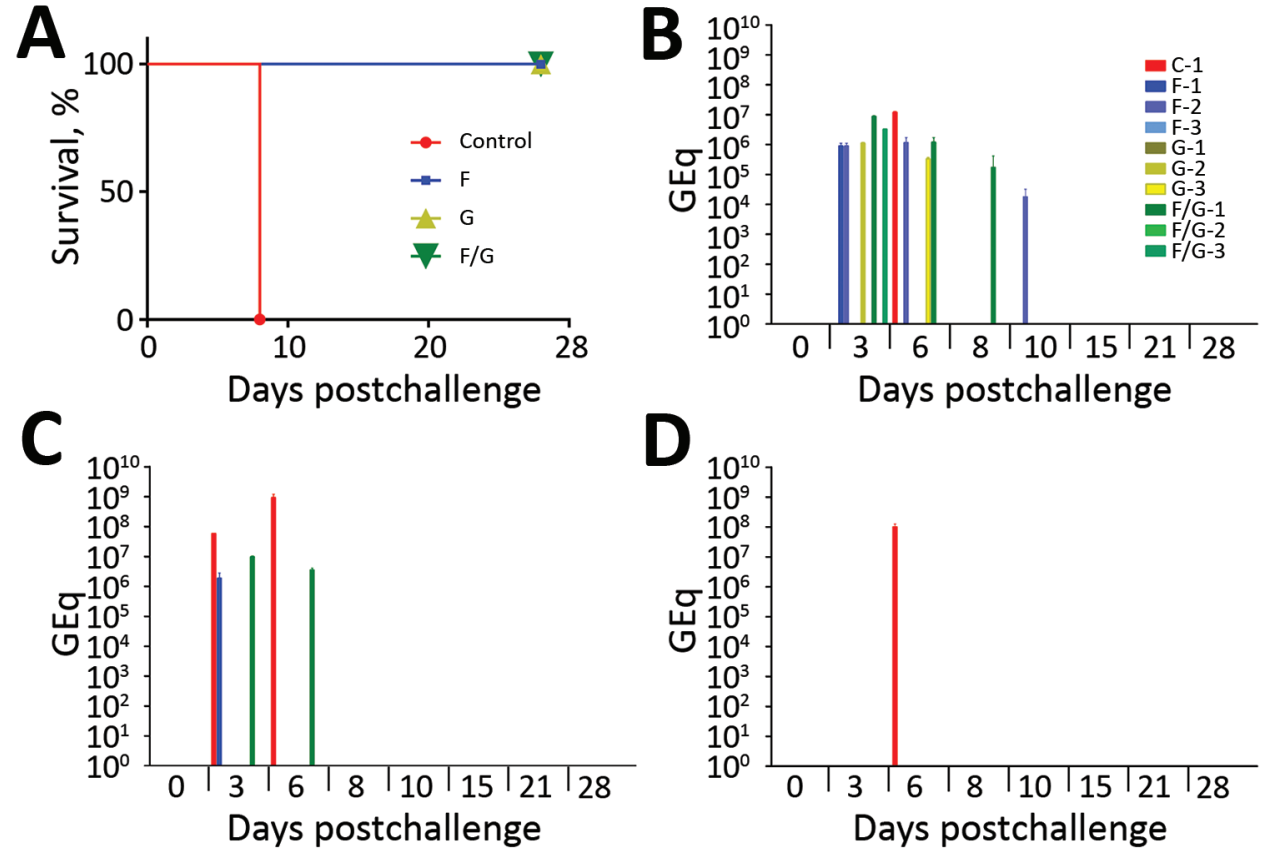
Table 1. $\mathrm{NiV}_{\mathrm{B}}$ serum neutralization titers in vaccinated African green monkeys (Chlorocebus aethiops)*

\begin{tabular}{lcccc}
\hline Vaccine & Animal no. & Day $-28 \dagger$ & Day 0† & Day 28† \\
\hline None & C-1 & $<20$ & $<20$ & $40 \ddagger$ \\
\hline F only vaccine & F-1 & $<20$ & 640 & 1,280 \\
& F-2 & $<20$ & 160 & 2,560 \\
& F-3 & $<20$ & 320 & 5,120 \\
\hline G only vaccine & G-1 & $<20$ & 640 & 5,120 \\
& G-2 & $<20$ & 640 & 5,120 \\
& G-3 & $<20$ & 640 & 5,120 \\
\hline F+G vaccine & F/G-1 & $<20$ & 640 & 2,560 \\
& F/G-2 & $<20$ & 640 & 5,120 \\
& F/G-3 & $<20$ & 640 & 2,560 \\
\hline
\end{tabular}

*Titers are reciprocal serum dilution at which $50 \%$ of virus was neutralized. $\mathrm{NiV}$, Nipah virus; $\mathrm{NiV}_{\mathrm{B}}$, NiV Bangladesh strain.

†Day postchallenge.

$\ddagger$ Terminal day 8 postchallenge.

nasal and oral swab samples and whole blood samples (Figure 1, panels B-D). We detected $\mathrm{NiV}_{\mathrm{B}}$ genome equivalents (GEq) from nasal swab samples (Figure 1, panel B) in the control, F, G, and F/G groups. The following animals were positive for viral RNA: C-1 at $6 \mathrm{dpc}$; F-1 at $3 \mathrm{dpc} ; \mathrm{F}-2$ at 3, 6, and $10 \mathrm{dpc}$; G-1 at $3 \mathrm{dpc} ; \mathrm{G}-3$ at 6 dpc; F/G-1 at 3, 6, and $8 \mathrm{dpc}$; and F/G-3 at 3 dpc. At 6 dpc, when C-1 was positive for NiV RNA in nasal swab samples, the levels were $>1 \log$ higher than they were for the NiV-antigen vaccinated groups $\mathrm{F}, \mathrm{G}$, and $\mathrm{F} / \mathrm{G}$. Oral swab samples were negative for NiV RNA in all animals in the G-vaccinated group (Figure 1, panel C), and $\mathrm{NiV}_{\mathrm{B}}$ GEq were detected from oral swab samples in the control, $\mathrm{F}$, and $\mathrm{F} / \mathrm{G}$ groups. The following animals were positive for viral RNA: C-1 at 3 and $6 \mathrm{dpc}, \mathrm{F}-1$ at $3 \mathrm{dpc}$, and F/G1 at 3 and 6 dpc. Within these oral swab sample results, C-1 had NiV RNA levels up to 100-fold higher than the $\mathrm{F}$ and $\mathrm{F} / \mathrm{G}$ animals that had positive oral swab samples (Figure 1, panel C). Unlike the results for swab samples, which represent tissues initially exposed to NiV, systemic and circulating $\mathrm{NiV}_{\mathrm{B}} \mathrm{GEq}$ were not detected in whole blood from animals in the F, G, and F/G groups, whereas the control animal was positive in the blood sample from $6 \mathrm{dpc}$ (Figure 1, panel D). The lack of systemic and circulating detection of $\mathrm{NiV}_{\mathrm{B}}$ RNA correlated with survival (Table 2; Figure 1, panel A).

\section{Gross Pathologic, Histopathologic, and Immunohistochemical Analyses of $\mathrm{NiV}_{b}$-Infected African Green Monkeys}

In the $F, G$, and $F / G$ groups, we observed no gross pathologic findings at study endpoint. However, in the control animal that died of $\mathrm{NiV}_{\mathrm{B}}$ infection, gross pathologic findings included serosanguinous pleural effusion, failure of all lung lobes to collapse with severe pulmonary hemorrhage and congestion, and multifocal to coalescing hemorrhage of the mucosal surface of the urinary bladder.

Lung sections examined from the control animal had moderate lymphoplasmacytic interstitial pneumonia characterized by a diffuse thickening of alveolar septae by moderate numbers of lymphocytes, plasma cells, polymerized fibrin, and edema fluid. The alveolar spaces were flooded by edema fluid, polymerized fibrin, foamy alveolar macrophages, and cellular debris. Endothelial syncytial cells were most apparent in medium- to small- caliber vessels (Figure 3, panel A). The animals in the F, G, and F/G groups had no major histologic findings in the lung sections (Figure 3, panels C, E, G). Immunohistochemical analysis revealed strong NiV antigen immunoreactivity within scattered alveolar macrophages and the endothelium of the alveolar septae and syncytial cells within medium- to small- caliber vessels in up to $\approx 75 \%$ of the examined pulmonary tissues (Figure 3, panel B). The lung sections of the F, G, and F/G groups were devoid of detectable NiV antigen (Figure 3, panels D, F, H).

Spleen sections from the control animal were depleted of lymphocytes in the multifocal follicular germinal centers within the splenic white pulp and were effaced by hemorrhage, fibrin, syncytial cell formation (Figure 4, panel A). Spleens from the F, G, and F/G groups had no major histologic findings (Figure 4, panels C, E, G). Immunohistochemical analysis of the spleen from the

\begin{tabular}{|c|c|c|c|c|}
\hline Animal no. & Sex & Group & Clinical illness & Clinical and gross pathology findings $\dagger$ \\
\hline $\mathrm{C}-1$ & $\mathrm{~F}$ & $\begin{array}{c}\text { Control } \Delta \mathrm{G} \\
\text { vaccine }\end{array}$ & $\begin{array}{l}\text { Loss of appetite (d 6- } \\
\text { 8); labored breathing } \\
\text { (d 6-8). Died on d } 8 .\end{array}$ & $\begin{array}{l}\text { Lymphopenia (d 6); serosanguinous nasal and oral discharge (d 8), } \\
\text { serosanguinous pleural fluid, severely inflated, enlarged lungs with } \\
\text { severe congestion and hemorrhage of all lobes, multifocal to coalescing } \\
\text { hemorrhage of the mucosal surface of the urinary bladder. }\end{array}$ \\
\hline $\mathrm{F}-1$ & $\mathrm{~F}$ & F vaccine & None & $\begin{array}{l}\text { Thrombocytopenia (d 15); >3 fold increase in ALT (d 6), >3 fold increase } \\
\text { in AST }\end{array}$ \\
\hline $\mathrm{F}-2$ & M & F vaccine & None & None \\
\hline $\mathrm{F}-3$ & M & F vaccine & None & Increase in CRP (d 6) \\
\hline G-1 & $\mathrm{F}$ & G vaccine & None & None \\
\hline G-2 & M & $\mathrm{G}$ vaccine & None & None \\
\hline G-3 & M & $\mathrm{G}$ vaccine & None & None \\
\hline F/G-1 & $F$ & $F+G$ vaccine & None & Increase in CRP (d 8) \\
\hline F/G-2 & M & $F+G$ vaccine & None & Thrombocytopenia (d 21, d 28); increase in CRP (d 8, d 10, d 15) \\
\hline F/G-3 & M & $F+G$ vaccine & None & Thrombocytopenia (d 8) \\
\hline
\end{tabular}

${ }^{*} \mathrm{ALT}$, alanine aminotransferase; AST, aspartate aminotransferase; CRP, C-reactive protein.

†Lymphopenia is defined as $a \geq 30 \%$ decrease in number of lymphocytes; thrombocytopenia is defined as a $\geq 30 \%$ decrease in number of platelets. 
Figure 2. Groups of African green monkeys (Chlorocebus aethiops) receiving recombinant vesicular stomatitis virus (rVSV) vaccine against Nipah virus Bangladesh strain $\left(\mathrm{NiV}_{\mathrm{B}}\right)$. Triangles indicate days of vaccination; arrows indicate days of sampling; and asterisk $\left(^{*}\right)$ indicates day of challenge. Red indicates control group $\left(G_{\text {Ind }}{ }^{*} r V S V-\Delta G-G F P\right.$ expressing no glycoprotein); blue indicates $\mathrm{F}$ group $\left(\mathrm{G}_{\text {Ind }}{ }^{*} \mathrm{rVSV}-\mathrm{NiV}_{\mathrm{B}} / \mathrm{F}-\right.$ GFP expressing the $\mathrm{NiV}_{\mathrm{B}} \mathrm{F}$ protein); yellow indicates $G$ group ( $\mathrm{G}_{\text {Ind }}{ }^{*} \mathrm{rVSV}-\mathrm{NiV} \mathrm{B}_{\mathrm{B}}$ /G-GFP expressing the $\mathrm{NiV}_{\mathrm{B}} \mathrm{G}$ protein);

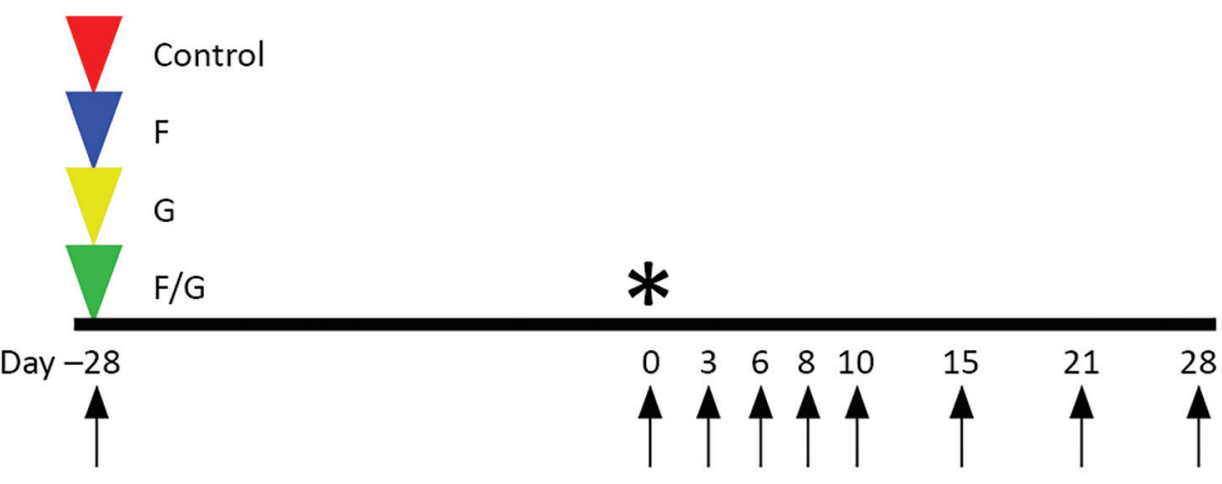
$F / G$ group (single-cycle infectious virions with $\mathrm{NiV}_{\mathrm{B}} \mathrm{F}$ and $\mathrm{G}$ proteins on the cell surface). $\mathrm{F}$, fusion; $\mathrm{G}$, attachment

control animal revealed strong immunoreactivity for $\mathrm{NiV}$ antigen within the endothelium, syncytial cells, and scattered mononuclear cells in up to $\approx 50 \%$ of the examined splenic tissue (Figure 4, panel B), whereas the spleen sections of groups $F, G$, and $F / G$ were devoid of detectable $\mathrm{NiV}$ antigen (Figure 4, panels D, F, H).

\section{Discussion}

An important step in the preclinical development of a vaccine is efficacy testing in standards of animal models of disease. For NiV, the standard is the African green monkey model. Although the initial studies on the $\mathrm{NiV}_{\mathrm{M}}$ model in African green monkeys were reported as near uniformly lethal, data from several groups have revealed the model is not $100 \%$ lethal, depending on dose and route of infection $(5,24,29-31,33,34)$. Combining the control animals from these studies, in which African green monkeys were challenged with various combinations of routes (e.g., intratracheal, intranasal, intraperitoneal, oral, small particle aerosol) at various doses, revealed that 18 (72\%) of 25 animals died; however, most of the control animals were positive for circulating NiV RNA and had signs of clinical disease to varying degrees. Historically, our previous studies with the $\mathrm{NiV}_{\mathrm{B}}$ model has resulted in the deaths of all 14 control African green monkeys; the mean time to death was 7.14 days (Figure 1, panel A). We recently compared the pathogenesis of $\mathrm{NiV}_{\mathrm{M}}$ and $\mathrm{NiV}_{\mathrm{B}}$ strains in African green monkeys and observed that $\mathrm{NiV}_{\mathrm{B}}$ caused more pulmonary and splenic pathologic findings (30). We also observed the efficacy of time to treatment post-NiV challenge with a human monoclonal antibody m102.4 was shorter for $\mathrm{NiV}_{B}$-infected animals than for $\mathrm{NiV}_{\mathrm{M}}$-infected animals (30). With these animal data in mind and the fact that $\mathrm{NiV}_{\mathrm{B}}$ has been responsible for most $\mathrm{NiV}$ outbreaks since 2002, we wanted to test our rVSV
$\mathrm{NiV}$ vaccine vectors expressing $\mathrm{NiV}_{\mathrm{B}} \mathrm{F}$ and $\mathrm{G}$ proteins as immunogens, which had $100 \%$ efficacy against $\mathrm{NiV}_{\mathrm{M}}$ challenge in ferrets (21), against $\mathrm{NiV}_{\mathrm{B}}$ challenge in African green monkeys.

In this study, we vaccinated 1 control African green monkey with a nonglycoprotein rVSV vector control, $\mathrm{G}_{\text {Ind }} *$ rVSV- $\Delta \mathrm{G}-\mathrm{GFP}$, and 3 groups of 3 African green monkeys with $\mathrm{NiV}$ antigen vectors: $\mathrm{G}_{\mathrm{Ind}} * \mathrm{rVSV}-\Delta \mathrm{G}-$ $\mathrm{NiV}_{\mathrm{B}} / \mathrm{F}-\mathrm{GFP}, \mathrm{G}_{\text {Ind }} *$ rVSV- $\Delta \mathrm{G}-\mathrm{NiV} \mathrm{B}_{\mathrm{B}} / \mathrm{G}-\mathrm{GFP}$, or $\mathrm{G}_{\text {Ind }} *$ rVSV- $\Delta \mathrm{G}-\mathrm{NiV}_{\mathrm{B}} / \mathrm{F} / \mathrm{G}-\mathrm{GFP}$. The control animal, C-1, did not develop $\mathrm{NiV}_{\mathrm{B}}$ neutralizing antibodies by the day of challenge; had detectable circulating NiV RNA at $6 \mathrm{dpc}$; had clinical signs of NiV-mediated disease; and ultimately died of infection, showing typical NiV gross pathology and histopathologic findings. Conversely, the $3 \mathrm{rVSV}$ NiV vaccine groups had animals in which detectable circulating NiV F, G, or F and G IgG developed, and circulating neutralizing antibody titers developed in all 3 groups by 28 days postvaccination. Each vaccine cohort had detectable $\mathrm{NiV}_{\mathrm{B}}$ RNA in nasal swab samples and only the $\mathrm{F}$ and $\mathrm{F} / \mathrm{G}$ groups in oral swab samples, but none of the cohorts had any detectable circulating $\mathrm{NiV}_{\mathrm{B}}$ RNA throughout the course of the study. Consistent with the vaccine response from each cohort and the control of systemic spread of $\mathrm{NiV}_{\mathrm{B}}$ infection and control of NiV-mediated disease, all of the specifically vaccinated African green monkeys survived $\mathrm{NiV}_{\mathrm{B}}$ challenge.

The results of this study are similar to what we observed with these rVSV NiV constructs in the ferret model, which showed $100 \%$ protection regardless of the vaccine construct (21). Differences were that we found higher $\mathrm{PRNT}_{50}$ results for neutralizing antibody titers on day of challenge in this study and detected no circulating NiV RNA in the African green monkeys but did have detectable viral RNA at 6 dpc in the ferret study. Although we 

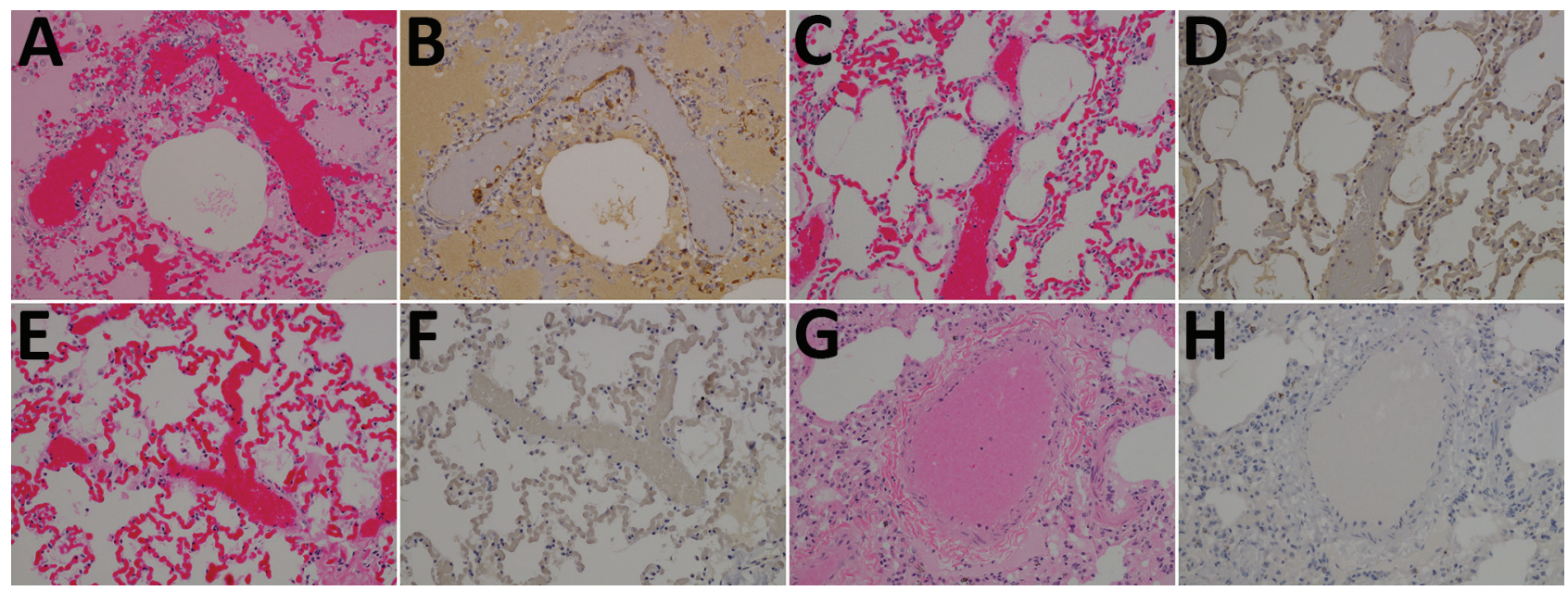

Figure 3. Results of testing for Nipah virus (NiV) in lung tissue from representative vaccinated African green monkeys (Chlorocebus aethiops). A, C, E, G) Hematoxylin and eosin staining; B, D, F, H) immunohistochemistry of tissues labeled with NiV N protein-specific polyclonal rabbit antibody. In stained tissue from the control animal (A), diffuse thickening of alveolar septae by moderate numbers of lymphocytes, plasma cells, polymerized fibrin, and edema fluid within the alveolar spaces were found; stained sections examined from the NiV F (C), NiV G (E), and NiV F/G (G) groups were unremarkable in comparison with sections from the control animal. In antibodylabeled tissue from the control animal (B), strong immunolabeling for NiV antigen with alveolar septae, scattered alveolar macrophages, and the endothelium of small caliber vessels were found, including syncytial cells with strong cytoplasmic immunolabeling for NiV antigen; no immunolabeling for NiV antigen was identified from the NiV F (D), NiV G (F), and NiV F/G (H) groups. Original magnification $\times 20$.

did not detect circulating viral RNA in the African green monkeys, the increase of neutralizing antibody titers at the study endpoint suggests sterilizing immunity was not achieved, and dosing or regimen will require further testing to reach sterilizing immunity with this single-round replication vaccine vector.

The single-round replication $\mathrm{rVSV} \mathrm{NiV}$ vectors in this study and the replication-competent rVSV-EBOVGP-NiVG (23) are the only vaccine vectors to show $100 \%$ single-dose vaccine efficacy against $\mathrm{NiV}$ in the African green monkey model. Although both studies used this model, they differed in several ways. Our study used $\mathrm{NiV}_{\mathrm{B}}$ and challenged through the intratracheal and intranasal routes, whereas the other study used $\mathrm{NiV}_{\mathrm{M}}$ by the intratracheal route only (intratracheal challenge route used in initial model [5]). Here, we report detectable levels of NiV RNA in nasal swab samples at early times postchallenge, whereas the rVSV-EBOV-GP-NiVG study did not report any detectable NiV RNA in nasal swab samples. Whether these differences resulted from use of the intranasal route as part of the challenge cannot be determined here; however, neither study reported circulating levels of NiV RNA, indicating the prevention of systemic spread of NiV infection. Both studies reported the detection of circulating neutralizing antibodies on the day of challenge (28 [this study] and 29 days postvaccination). However, we reported on PFU reduction, and the rVSV-EBOVGP-NiVG study reported on reduction of $20050 \%$ tissue culture infectious dose in a tissue culture infectious dose assay, so the peak neutralizing titers at $\mathrm{NiV}$ challenge cannot be directly compared.

The PRNT 50 titers we reported can be directly compared with the recombinant subunit $\mathrm{sG}_{\mathrm{HeV}}$ vaccine $\mathrm{NiV}$ study in African green monkeys that also was $100 \%$ efficacious (29), whereas we detected higher PRNT $_{50}$ titers against $\mathrm{NiV}$ from the single injection of single-round replication vectors (from 160 to 640; Table 1) versus the $\mathrm{PRNT}_{50}$ titers 2 weeks after boost vaccination (from 28 to 379 ) for the recombinant subunit $\mathrm{sG}_{\mathrm{HeV}}$ vaccine. However, these lower titers most likely are due to the $\mathrm{sG}_{\mathrm{HeV}}$ vaccine being heterotypic because the $\mathrm{PRNT}_{50}$ titers against $\mathrm{HeV}$ in a similar African green monkey study were $640-1,280$ on day of challenge (28). The development of neutralizing antibodies to the NiV glycoproteins after vaccination are important for protection, as highlighted by a single monoclonal antibody against the henipavirus $\mathrm{G}$ protein, $\mathrm{m} 102.4$, that is $100 \%$ protective against $\mathrm{HeV}, \mathrm{NiV}_{\mathrm{M}}$, and $\mathrm{NiV}_{\mathrm{B}}$ when administered at least 3 dpc $(30,31,35)$.

In our study, the $\mathrm{F}$ cohort did not produce as consistent a neutralizing antibody titer response as did the $\mathrm{G}$ and $\mathrm{F} / \mathrm{G}$ cohorts. Further analysis also revealed that, although no major changes occurred in hematologic and blood chemistry results for any of the vaccine cohorts, minor changes occurred in the $\mathrm{F}$ and $\mathrm{F} / \mathrm{G}$ cohorts (Table 1). These data, taken together with the lack of detectable $\mathrm{NiV}_{\mathrm{B}}$ RNA in the oral swab samples of the G group, suggest the rVSV NiV G vector might be the better option among the 3 vaccine vectors. 

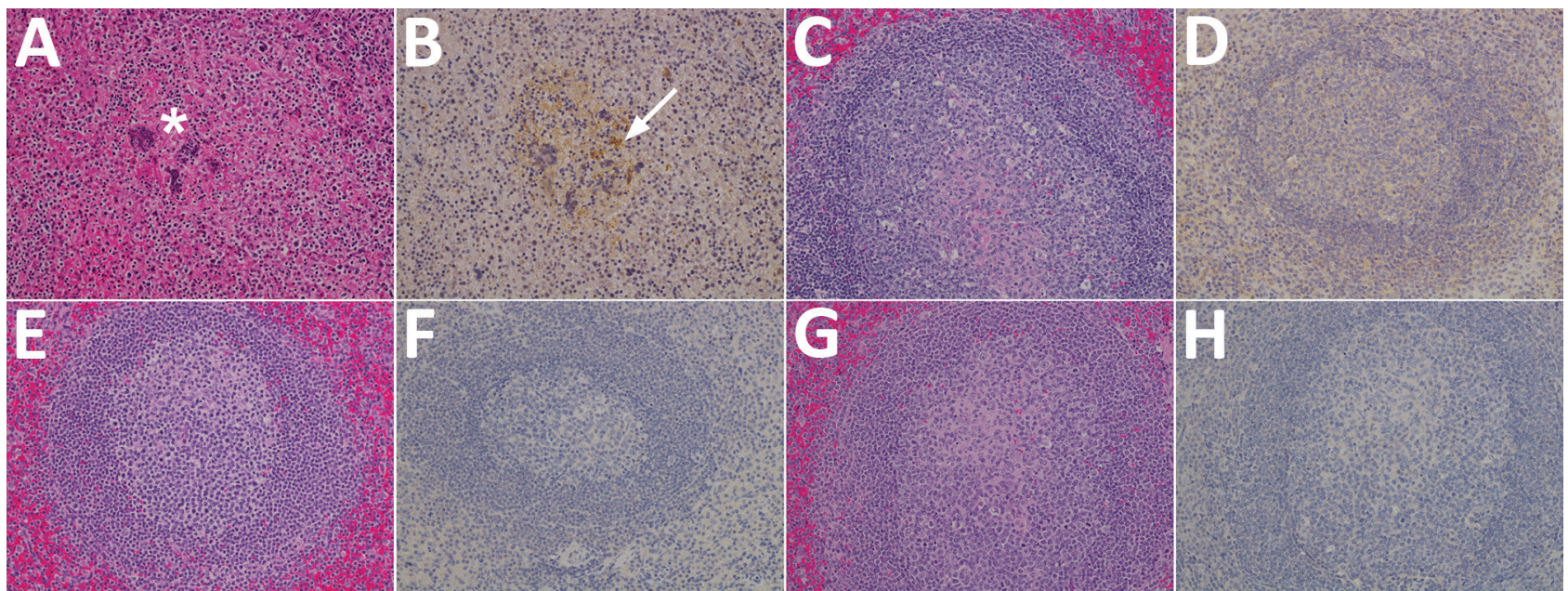

Figure 4. Results of testing for Nipah virus (NiV) in spleen tissue from representative vaccinated African green monkeys (Chlorocebus aethiops). A, C, E, G) Hematoxylin and eosin staining; B, D, F, H) immunohistochemistry of tissues labeled with NiV N protein-specific polyclonal rabbit antibody. In stained tissue from the control animal $(A)$, moderate necrosis and drop out of the white pulp $\left(^{*}\right)$, with hemorrhage, and fibrin within germinal centers are seen; stained sections examined from the NiV F (C), NiV G (E), and NiV F/G (G) groups were devoid of any significant lesions compared with sections from the control animal. In antibody-labeled tissues from the control animal (B), strong immunolabeling for NiV antigen with scattered mononuclear cells (white arrow) and syncytial cells within germinal centers were found, and the endothelium of small caliber vessels had strong cytoplasmic immunolabeling for NiV antigen; no immunolabeling for NiV antigen was identified from the NiV F (D), NiV G $(F)$, and NiV F/G $(H)$ groups. Original magnification $\times 20$.

In summary, we found that single-round replication rVSV vectors against $\mathrm{NiV}_{\mathrm{B}}$ provided $100 \%$ efficacy against $\mathrm{NiV}_{\mathrm{B}}$ challenge using a single-dose regimen. The rVSV vaccine platform has received attention recently because the replication-competent rVSV-ZEBOV GP vaccine vector against EBOV has now been given to $>16,000$ humans in clinical trials ranging from phase 1 to phase 3 and has been safe and efficacious (36); however, data for pregnant women and immunocompromised persons are not yet available. A single-round replication rVSV vaccine vector that is immunogenic and efficacious would have an attractive safety profile. Whether these single-round replication rVSV NiV vaccine vectors are as safe as the recombinant subunit $\mathrm{sG}_{\mathrm{HeV}}$ vaccine has yet to be determined, and the subunit vaccine has yet to be tested with a single-dose vaccine regimen. Although multidose vaccine regimens would be a potential strategy for laboratory and healthcare workers and for first responders in stable settings with defined risk for an NiV outbreak, an outbreak setting or a case of deliberate release of $\mathrm{NiV}$ would require rapid protection with a single administration of vaccine. The single-dose strategy was successfully enacted using a close-contact ring vaccination strategy with the rVSV-ZEBOV-GP vaccine at the end of the 2013-2016 EBOV epidemic (37-39). The strategy was so successful that it became the World Health Organization recommendation for future EBOV outbreaks and has recently been set into motion in the ongoing outbreak in the Democratic Republic of the Congo (40). Recent studies also suggest that the ring vaccination strategy for viruses such as EBOV (depending on transmissibility) that are endemic to countries that might not be able to afford a mass herd-immunity vaccination strategy might be more effective than mass vaccinations at controlling outbreaks (41). Further studies should examine the time to immunity of the $\mathrm{G}_{\text {Ind }}$ * rVSV- $\Delta \mathrm{G}-\mathrm{NiV}_{\mathrm{B}} / \mathrm{G}$ in the $\mathrm{NiV}_{\mathrm{B}}$ African green monkey model because these data will be instrumental in providing information about whether this vaccine vector could be implemented in a ring vaccination strategy during future NiV outbreaks, such as the current one in India (2).

\section{Acknowledgments}

We thank the staff of the University of Texas Medical Branch Animal Resources Center for animal husbandry, Robert W. Cross for assistance with the animal study, and Natalie Dobias for assistance with histologic processing. We thank Thomas G. Ksiazek for kindly providing the $\mathrm{NiV}_{\mathrm{B}}$ isolate used in this study.

This study was supported in part by National Institutes of Health (U01 AI082121 for research and UC7AI094660 for BSL-4 operations) and by funds provided to T.W.G. by the UTMB Department of Microbiology and Immunology.

\section{About the Author}

Dr. Mire is an associate professor in the Department of Microbiology and Immunology at the University of Texas Medical Branch-Galveston and the Galveston National Laboratory. His research focuses on understanding host-pathogen interactions of highly pathogenic RNA viruses. 


\section{References}

1. Wang L, Harcourt BH, Yu M, Tamin A, Rota PA, Bellini WJ, et al. Molecular biology of Hendra and Nipah viruses. Microbes Infect. 2001;3:279-87. http://dx.doi.org/10.1016/S1286-4579(01)01381-8

2. Chatterjee P. Nipah virus outbreak in India. Lancet. 2018;391:2200. http://dx.doi.org/10.1016/S0140-6736(18)31252-2

3. Halpin K, Hyatt AD, Fogarty R, Middleton D, Bingham J, Epstein JH, et al.; Henipavirus Ecology Research Group. Pteropid bats are confirmed as the reservoir hosts of henipaviruses: a comprehensive experimental study of virus transmission. Am J Trop Med Hyg. 2011;85:946-51. http://dx.doi.org/10.4269/ ajtmh.2011.10-0567

4. Bossart KN, Zhu Z, Middleton D, Klippel J, Crameri G, Bingham J, et al. A neutralizing human monoclonal antibody protects against lethal disease in a new ferret model of acute Nipah virus infection. PLoS Pathog. 2009;5:e1000642. http://dx.doi.org/10.1371/journal.ppat.1000642

5. Geisbert TW, Daddario-DiCaprio KM, Hickey AC, Smith MA, Chan YP, Wang LF, et al. Development of an acute and highly pathogenic nonhuman primate model of Nipah virus infection. PLoS One. 2010;5:e10690. http://dx.doi.org/10.1371/ journal.pone. 0010690

6. Hooper P, Zaki S, Daniels P, Middleton D. Comparative pathology of the diseases caused by Hendra and Nipah viruses. Microbes Infect. 2001;3:315-22. http://dx.doi.org/10.1016/S1286-4579(01) 01385-5

7. Wong KT, Grosjean I, Brisson C, Blanquier B, Fevre-Montange M, Bernard A, et al. A golden hamster model for human acute Nipah virus infection. Am J Pathol. 2003;163:2127-37. http://dx.doi.org/ 10.1016/S0002-9440(10)63569-9

8. Chua KB, Bellini WJ, Rota PA, Harcourt BH, Tamin A, Lam SK, et al. Nipah virus: a recently emergent deadly paramyxovirus. Science. 2000;288:1432-5. http://dx.doi.org/ 10.1126/science.288.5470.1432

9. Uppal PK. Emergence of Nipah virus in Malaysia. Ann N Y Acad Sci. 2000;916:354-7. http://dx.doi.org/10.1111/j.1749-6632.2000. tb05312.x

10. Ching PKG, de los Reyes VC, Sucaldito MN, Tayag E, Columna-Vingno AB, Malbas FF Jr, et al. Outbreak of henipavirus infection, Philippines, 2014. Emerg Infect Dis. 2015;21:328-31. http://dx.doi.org/10.3201/eid2102.141433

11. Gurley ES, Montgomery JM, Hossain MJ, Bell M, Azad AK, Islam MR, et al. Person-to-person transmission of Nipah virus in a Bangladeshi community. Emerg Infect Dis. 2007;13:1031-7. http://dx.doi.org/10.3201/eid1307.061128

12. Harcourt BH, Lowe L, Tamin A, Liu X, Bankamp B, Bowden N, et al. Genetic characterization of Nipah virus, Bangladesh, 2004. Emerg Infect Dis. 2005;11:1594-7. http://dx.doi.org/10.3201/ eid1110.050513

13. Hsu VP, Hossain MJ, Parashar UD, Ali MM, Ksiazek TG, Kuzmin I, et al. Nipah virus encephalitis reemergence, Bangladesh. Emerg Infect Dis. 2004;10:2082-7. http://dx.doi.org/10.3201/ eid1012.040701

14. Lo MK, Lowe L, Hummel KB, Sazzad HM, Gurley ES, Hossain MJ, et al. Characterization of Nipah virus from outbreaks in Bangladesh, 2008-2010. Emerg Infect Dis. 2012;18:248-55. http://dx.doi.org/10.3201/eid1802.111492

15. Luby SP, Hossain MJ, Gurley ES, Ahmed BN, Banu S, Khan SU, et al. Recurrent zoonotic transmission of Nipah virus into humans, Bangladesh, 2001-2007. Emerg Infect Dis. 2009;15:1229-35. http://dx.doi.org/10.3201/eid1508.081237

16. Homaira N, Rahman M, Hossain MJ, Epstein JH, Sultana R, Khan MS, et al. Nipah virus outbreak with person-to-person transmission in a district of Bangladesh, 2007. Epidemiol Infect. 2010;138:1630-6. http://dx.doi.org/10.1017/ S0950268810000695
17. Guillaume V, Contamin H, Loth P, Georges-Courbot MC, Lefeuvre A, Marianneau P, et al. Nipah virus: vaccination and passive protection studies in a hamster model. J Virol. 2004;78:834-40. http://dx.doi.org/10.1128/JVI.78.2.834-840.2004

18. Weingartl HM, Berhane Y, Caswell JL, Loosmore S, Audonnet J-C, Roth JA, et al. Recombinant Nipah virus vaccines protect pigs against challenge. J Virol. 2006;80:7929-38. http://dx.doi.org/ 10.1128/JVI.00263-06

19. Ploquin A, Szécsi J, Mathieu C, Guillaume V, Barateau V, Ong KC, et al. Protection against henipavirus infection by use of recombinant adeno-associated virus-vector vaccines. J Infect Dis. 2013;207:469-78. http://dx.doi.org/10.1093/infdis/ jis699

20. Lo MK, Bird BH, Chattopadhyay A, Drew CP, Martin BE, Coleman JD, et al. Single-dose replication-defective VSV-based Nipah virus vaccines provide protection from lethal challenge in Syrian hamsters. Antiviral Res. 2014;101:26-9. http://dx.doi.org/ 10.1016/j.antiviral.2013.10.012

21. Mire CE, Versteeg KM, Cross RW, Agans KN, Fenton KA, Whitt MA, et al. Single injection recombinant vesicular stomatitis virus vaccines protect ferrets against lethal Nipah virus disease. Virol J. 2013;10:353. http://dx.doi.org/10.1186/ 1743-422X-10-353

22. DeBuysscher BL, Scott D, Marzi A, Prescott J, Feldmann H. Single-dose live-attenuated Nipah virus vaccines confer complete protection by eliciting antibodies directed against surface glycoproteins. Vaccine. 2014;32:2637-44. http://dx.doi.org/ 10.1016/j.vaccine.2014.02.087

23. Prescott J, DeBuysscher BL, Feldmann F, Gardner DJ, Haddock E, Martellaro C, et al. Single-dose live-attenuated vesicular stomatitis virus-based vaccine protects African green monkeys from Nipah virus disease. Vaccine. 2015;33:2823-9. http://dx.doi.org/10.1016/ j.vaccine.2015.03.089

24. Yoneda M, Georges-Courbot M-C, Ikeda F, Ishii M, Nagata N, Jacquot F, et al. Recombinant measles virus vaccine expressing the Nipah virus glycoprotein protects against lethal Nipah virus challenge. PLoS One. 2013;8:e58414. http://dx.doi.org/10.1371/ journal.pone.0058414

25. Mungall BA, Middleton D, Crameri G, Bingham J, Halpin K, Russell G, et al. Feline model of acute nipah virus infection and protection with a soluble glycoprotein-based subunit vaccine. J Virol. 2006;80:12293-302. http://dx.doi.org/10.1128/ JVI.01619-06

26. Pallister J, Middleton D, Wang LF, Klein R, Haining J, Robinson R, et al. A recombinant Hendra virus G glycoproteinbased subunit vaccine protects ferrets from lethal Hendra virus challenge. Vaccine. 2011;29:5623-30. http://dx.doi.org/10.1016/ j.vaccine.2011.06.015

27. Pallister JA, Klein R, Arkinstall R, Haining J, Long F, White JR, et al. Vaccination of ferrets with a recombinant $G$ glycoprotein subunit vaccine provides protection against Nipah virus disease for over 12 months. Virol J. 2013;10:237. http://dx.doi.org/10.1186/1743-422X-10-237

28. Mire CE, Geisbert JB, Agans KN, Feng YR, Fenton KA, Bossart KN, et al. A recombinant Hendra virus G glycoprotein subunit vaccine protects nonhuman primates against Hendra virus challenge. J Virol. 2014;88:4624-31. http://dx.doi.org/10.1128/ JVI.00005-14

29. Bossart KN, Rockx B, Feldmann F, Brining D, Scott D, LaCasse R, et al. A Hendra virus $G$ glycoprotein subunit vaccine protects African green monkeys from Nipah virus challenge. Sci Transl Med. 2012;4:146ra107. http://dx.doi.org/10.1126/scitranslmed. 3004241

30. Mire CE, Satterfield BA, Geisbert JB, Agans KN, Borisevich V, Yan L, et al. Pathogenic differences between Nipah virus Bangladesh and Malaysia strains in primates: implications for 
antibody therapy. Sci Rep. 2016;6:30916. http://dx.doi.org/10.1038/ srep30916

31. Geisbert TW, Mire CE, Geisbert JB, Chan YP, Agans KN, Feldmann F, et al. Therapeutic treatment of Nipah virus infection in nonhuman primates with a neutralizing human monoclonal antibody. Sci Transl Med. 2014;6:242ra82. http://dx.doi. org/10.1126/scitranslmed.3008929

32. Whitt MA, Geisbert TW, Mire CE. Single-vector, single-injection recombinant vesicular stomatitis virus vaccines against highcontainment viruses. Methods Mol Biol. 2016;1403:295-311. http://dx.doi.org/10.1007/978-1-4939-3387-7_16

33. Cong Y, Lentz MR, Lara A, Alexander I, Bartos C, Bohannon JK, et al. Loss in lung volume and changes in the immune response demonstrate disease progression in African green monkeys infected by small-particle aerosol and intratracheal exposure to Nipah virus. PLoS Negl Trop Dis. 2017;11:e0005532. http://dx.doi.org/10.1371/journal.pntd.0005532

34. Johnston SC, Briese T, Bell TM, Pratt WD, Shamblin JD, Esham HL, et al. Detailed analysis of the African green monkey model of Nipah virus disease. PLoS One. 2015;10:e0117817. http://dx.doi.org/10.1371/journal.pone.0117817

35. Bossart KN, Geisbert TW, Feldmann H, Zhu Z, Feldmann F, Geisbert JB, et al. A neutralizing human monoclonal antibody protects African green monkeys from hendra virus challenge. Sci Transl Med. 2011;3:105ra103. http://dx.doi.org/10.1126/ scitranslmed.3002901

36. Suder E, Furuyama W, Feldmann H, Marzi A, de Wit E. The vesicular stomatitis virus-based Ebola virus vaccine: from concept to clinical trials. Hum Vaccin Immunother. 2018;14:210713. http://dx.doi.org/10.1080/21645515.2018.1473698
37. Gsell PS, Camacho A, Kucharski AJ, Watson CH, Bagayoko A Nadlaou SD, et al. Ring vaccination with rVSV-ZEBOV under expanded access in response to an outbreak of Ebola virus disease in Guinea, 2016: an operational and vaccine safety report. Lancet Infect Dis. 2017;17:1276-84. http://dx.doi.org/10.1016/ S1473-3099(17)30541-8

38. Henao-Restrepo AM, Camacho A, Longini IM, Watson CH, Edmunds WJ, Egger M, et al. Efficacy and effectiveness of an rVSV-vectored vaccine in preventing Ebola virus disease: final results from the Guinea ring vaccination, open-label, clusterrandomised trial (Ebola Ça Suffit!). Lancet. 2017;389:505-18. http://dx.doi.org/10.1016/S0140-6736(16)32621-6

39. Henao-Restrepo AM, Longini IM, Egger M, Dean NE, Edmunds WJ, Camacho A, et al. Efficacy and effectiveness of an rVSV-vectored vaccine expressing Ebola surface glycoprotein: interim results from the Guinea ring vaccination cluster-randomised trial. Lancet. 2015;386:857-66. http://dx.doi.org/10.1016/S0140$6736(15) 61117-5$

40. Wise J. WHO is "cautiously optimistic" about Ebola ring vaccination programme in DRC. BMJ. 2018;361:k2388. http://dx.doi.org/10.1136/bmj.k2388

41. Masterson SG, Lobel L, Carroll MW, Wass MN, Michaelis M. Herd immunity to Ebolaviruses is not a realistic target for current vaccination strategies. Front Immunol. 2018;9:1025. http://dx.doi.org/10.3389/fimmu.2018.01025

Address for correspondence: Thomas W. Geisbert, University of Texas Medical Branch, Microbiology and Immunology, 301 University Blvd, Galveston, TX 77550-0610, USA; email: twgeisbe@utmb.edu

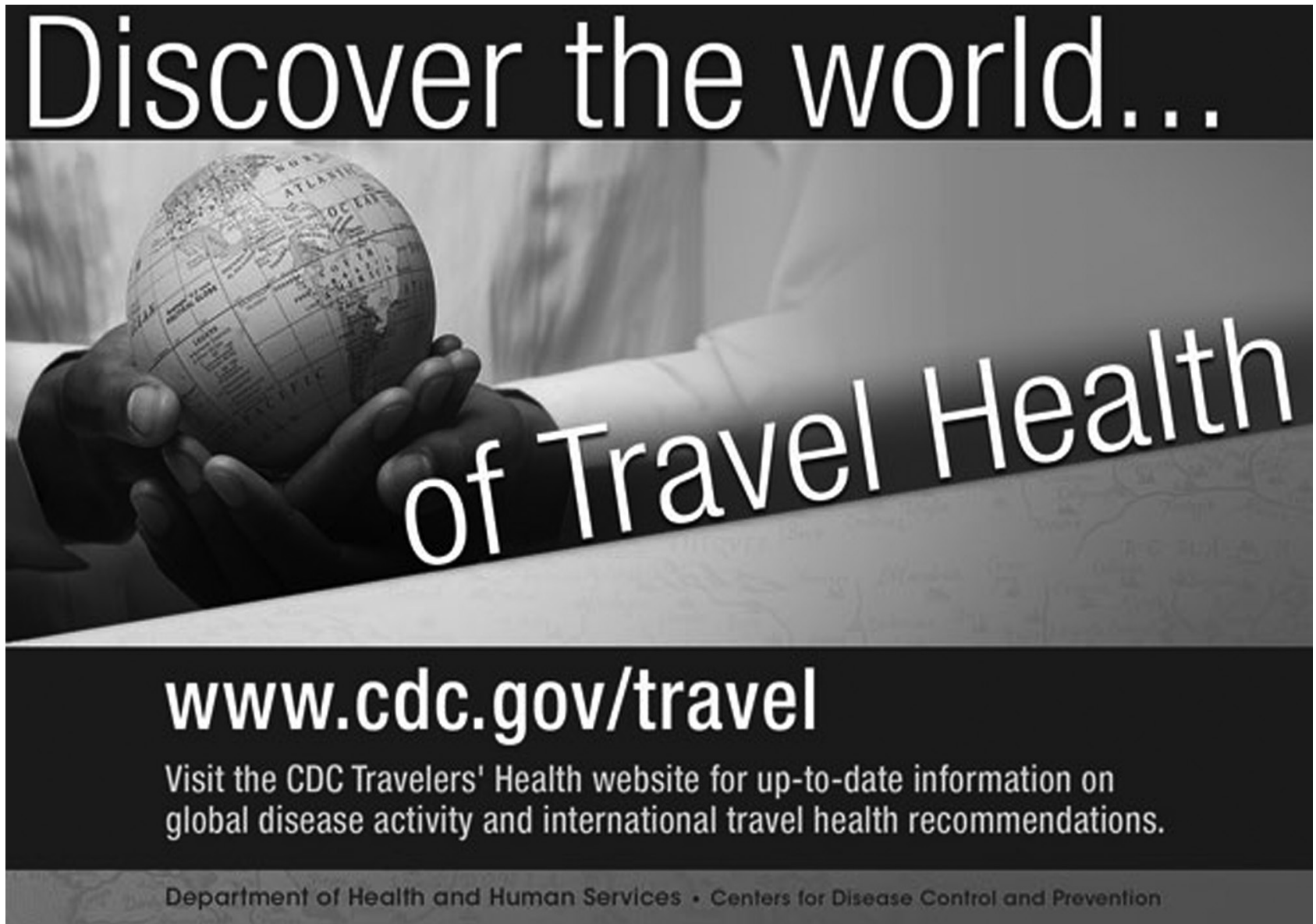

